\title{
Environmental benefits of incorporating palm oil fuel ash in cement concrete and cement mortar
}

\author{
G A Jokhio ${ }^{1,5}, H_{M}$ Hamada $^{2}$, A M Humada $^{3}$, Y Gul $^{4,}{ }^{*}$ and Abid Abu-Tair ${ }^{1}$ \\ ${ }^{1}$ Faculty of Engineering \& IT, The British University in D ubai, U nited A rab Emirates \\ ${ }^{2}$ Faculty of Civil Engineering and Earth Resources, University M alaysia Pahang, M alaysia \\ ${ }^{3}$ Faculty of Engineering, University of K irkuk, I raq \\ ${ }^{4}$ College of A rchitecture and Design, Al G hurair University, D ubai, U nited A rab E mirates
}

\begin{abstract}
Palm oil fuel ash (POFA) is a by-product waste material from palm oil with many economic and environmental benefits. A lack of enough information on the advantages of POFA in the concrete production in various proportions was the main cause to carry out this work. This paper shows advantages of POFA as a partial replacement of cement in concrete production, especially cement mortar. The data collection has been done from the literature review related to the use of POFA as partial cement replacement in the production of cement concrete and mortar. Therefore, this paper can potentially become a guide for researchers and manufacturers to use POFA in various proportions to replace the ordinary Portland cement $(O P C)$ in cement concrete and mortar. The positive and negative impact resulting from this material has been discussed carefully. This study recommends that researchers and academics should perform more experimental works in order to illustrate the desired benefits from POFA as cement replacement, thus mitigate the adverse environmental impacts of cement.
\end{abstract}

Keywords: Palm oil fuel ash, environment friendly concrete, agricultural waste byproducts

\section{Introduction}

South-east A sian countries produce the most products from oil palm, which grows their abundantly owing to their geographical and ecological conditions [1,2]. They depend on the agriculture industry to promote their economies because of receiving abundant rainfall throughout the year which makes them suitable for plantation [3]. Production of palm oil forms the most proportion of vegetable oil production in the world which was more than 60 million tons in 2012, whereas the percentage of palm oil was more than $35 \%$ of the total vegetable oil in the same year $[2,4]$. Malaysia and Indonesia contribute to the largest production of palm oil in the world which was more than $80 \%$ of the total production, just $10 \%$ of that palm oil is used to cover the local demand and $90 \%$ is exported $[5,6]$. In 2011, the production rate of palm oil was $48 \%$ in Indonesia, $38 \%$ in Malaysia, and $3 \%$ in Thailand $[7,8,9]$. Increasing the production of palm oil leads to the generation of a huge quantity of waste materials such as POFA [10] that have high content of silica and serious effects on the surrounding environment if not used in other industries.

The cement industry is also facing a serious challenge in terms of the consumption of a very high amount of electricity and a very high cost to produce the quantity needed to meet the market requirements. Therefore, reducing emission of $\mathrm{CO}_{2}$ is the main impetus for scientists, academics and researchers to use alternative materials instead of cement in the concrete production [11]. The increase of cement content in the concrete automatically reflects in the increase of the construction cost [12] thus, the increase in the cement production will result in rise in the consumption of electrical energy, besides raising the $\mathrm{CO}_{2}$ emission, which can cause irreversible environmental damages [12, 13]. M any researchers studied adding POFA as a partial replacement of cement to get high compressive strength $[10,14,15]$ because the high silica content in it makes it a good pozzolanic material. Therefore, POFA considered one of the significant pozzolanic materials that contain a high quantity of silica in their chemical composition. It has been used to replace cement partially in order to get durable and high strength concrete [16, 17]. The emission of $\mathrm{CO}_{2}$ into the atmosphere due to cement production causes undesirable environmental impacts which contribute to the global warming. Therefore, many studies have been conducted to replace cement partially with suitable supplementary cementitious materials such as POFA, fly ash, silica fume, metakaolin and other pozzolanic materials in order to reduce the cement 
production and mitigate it impacts on the environmental conditions. This paper will show the advantages that can be acquired due to the incorporation of POFA in various percentages to the concrete as partial cement replacement. Heat of hydration, compressive strength, resistance to acids, resistance to the chlorides, and resistance to the sulphates will be discussed individually as depicted in Figure 1.

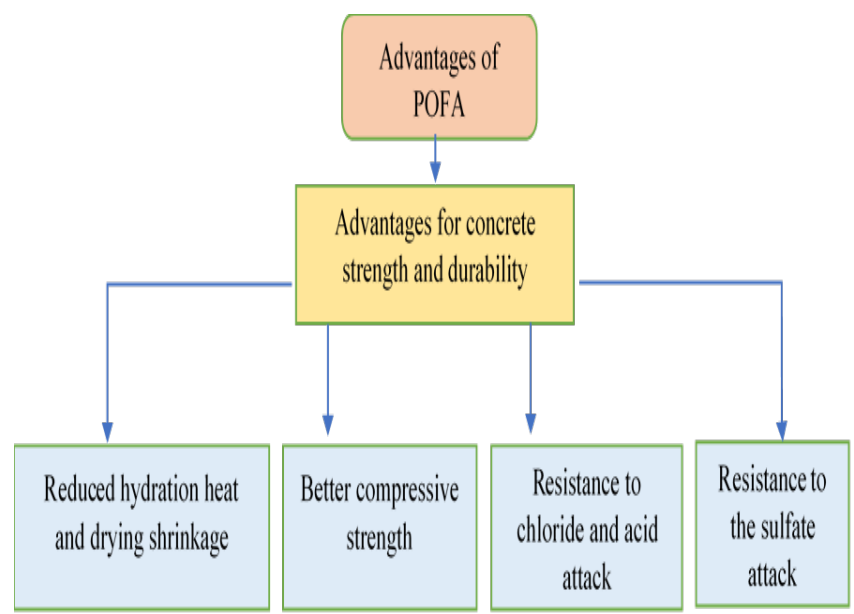

Figure 1: Advantages of the use of POFA in concrete

\section{Advantages of concrete containing pofa}

Several previous researchers have shown that the incorporation of POFA in concrete adds many advantages to the concrete properties especially in the durability aspects. Improving the microstructure and density of hardened concrete can be achieved by adding micro and $\mathrm{N}$ ano POFA as cement replacement in the concrete mix which result to improve the pozzolanic reaction as well $[18,19,20]$. The ability of POFA to produce further amounts of $\mathrm{C}$-S-H gels to increase the pozzolanic activity and its use as a filler in concrete mixture leads to improve the durability and mechanical properties of the hardened concrete $[21,22,23]$. Four properties within the concrete durability will be discussed in the following subsections to show the impact of the POFA to enhance these properties

\subsection{Reduced hydration heat ad drying shrinkage}

The hydration heat released from the fresh concrete containing ash is due to two reasons, the first reason is due to the release of hydration heat of cement, the second reason is due to the hydration heat released by the admixture reactions [24]. Hydration process of cement compounds is accompanied by heat generation resulting from the reaction of different compounds in cement with mixing water; this heat is a form of energy released to reach a stable state [22]. In a study by Lim et al. [25] it was shown that the de-carbonation process of POFA is due to the decomposition of the calcium carbonate between temperatures 400 and $600 \mathrm{OC}$ as shown in Figure 2. The hydration heat of Ground POFA (GPOFA) and
UItrafine POFA (UPOFA) mortar were similar somewhat, but they totally differed on the initial reading of the cement hydration heat. The study concluded that POFA in both types and regardless of its particle size has the ability to reduce the hydration temperature better than oil palm clinker (OPC) as shown in Figure 3.

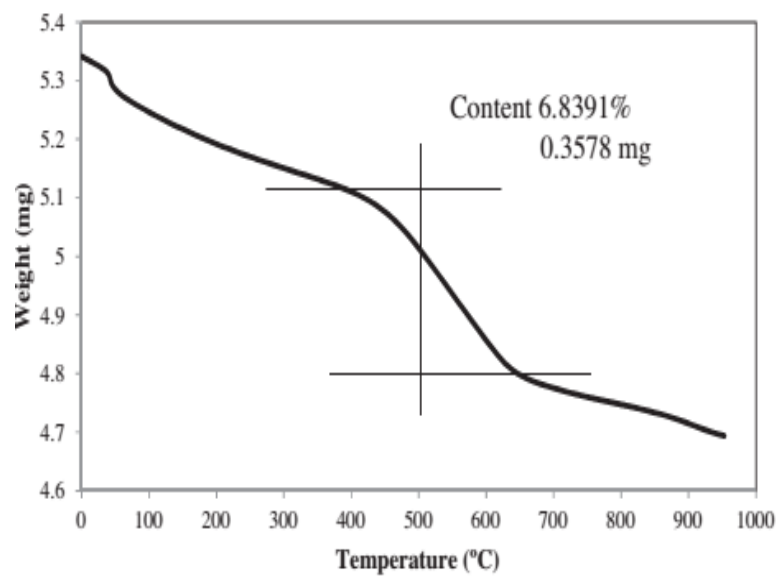

Figure 2: TGA results of POFA [25]

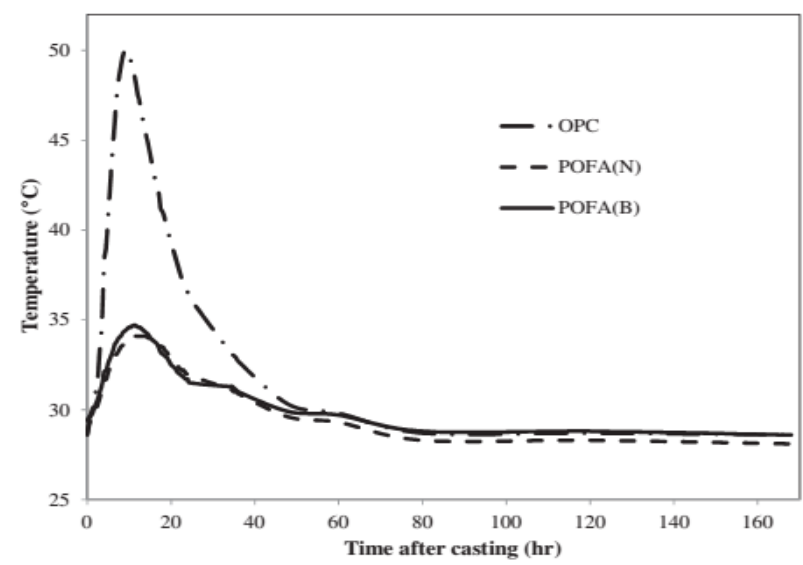

Figure 3: Hydration heat of OPC, GPOFA, and UPOFA [25]

Besides that Tay [26] showed that there is no significant impact of POFA addition on the water absorption, segregation, drying shrinkage, density, and soundness of cement. Drying shrinkage is the main cause for the occurrence of cracking, excessive deflection, stress re-distribution, pre-stress losses, and ingression of water and aggressive chemicals [27, 28]. Farzadnia et al. [29] conducted a study on the $30 \%$ POFA as cement replacement in concrete mix, it was noted that drying shrinkage was reduced by $7.5 \%$ within 28 days due to the addition of $\mathrm{N}$ ano silica to the concrete mix.

\subsection{Effects on concrete strength}

The compressive strength for concrete containing POFA, as well as its flexural and tensile strengths in same direction, were comparable to the control concrete sample for the percentage of replacement less than and up to $50 \%$ $[30,31,32]$. B ut, at the replacement percentage of cement at $50 \%$ by fine POFA, the compressive strength was $90 \%$

of the control sample value. This is due to the high fineness of POFA particles and high surface area which assists to improve chemical reactivity [33]. A Ithough the 
cement replacement by industrial waste will improve the

Table 1: Effect of POFA as cement replacement in various proportions on the concrete durability

\begin{tabular}{|c|c|c|}
\hline Ref & $\begin{array}{l}\text { Replacem } \\
\text { ent rate }\end{array}$ & $\begin{array}{l}\text { Effect of cement replacement by POFA } \\
\text { on the concrete properties }\end{array}$ \\
\hline [14] & $\begin{array}{c}10 \% \\
20 \%, 30 \%\end{array}$ & $\begin{array}{c}\text { Compressive strength at } 28 \text { days was } \\
60.9 \mathrm{M} \mathrm{Pa} \text { for concrete with } 20 \% \text { POFA, } \\
\text { while the control sample was } 58.5 \mathrm{M} \mathrm{Pa} \\
\text { only. }\end{array}$ \\
\hline [15] & $\begin{array}{c}10 \% \\
20 \%, 30 \%\end{array}$ & $\begin{array}{c}\text { The compressive strength will increase } \\
\text { with the curing age more than the } \\
\text { control sample by } 85.9 \mathrm{M} \mathrm{Pa} \text { for } 20 \% \\
\text { POFA. }\end{array}$ \\
\hline [38] & $\begin{array}{l}60 \% \\
80 \% \\
100 \%\end{array}$ & $\begin{array}{l}\text { 60\% and } 80 \% \text { POFA as cement } \\
\text { replacement appear high compressive } \\
\text { strength at later age more than cement } \\
\text { control }\end{array}$ \\
\hline [39] & $\begin{array}{c}20 \% \\
40 \%, 60 \% \\
\end{array}$ & $\begin{array}{l}\text { Improve the compressive strength in } \\
\text { later age of curing }\end{array}$ \\
\hline [40] & $\begin{array}{c}20 \% \\
40 \%, 60 \%\end{array}$ & $\begin{array}{c}\text { A chieve high compressive strength } \\
\text { more than } 90 \mathrm{M} \mathrm{Pa} \text { in } 28 \text { days of curing, } \\
\text { also gain about } 8 \% \text { in } 90 \text { days of curing } \\
\text { with category } 60 \% \text { POFA }\end{array}$ \\
\hline [40] & $\begin{array}{l}60 \% \\
80 \% \\
100 \%\end{array}$ & $\begin{array}{l}\text { The concrete samples were produced by } \\
\text { POFA achieved } 90 \% \text { of the } \\
\text { compressive strength in the traditional } \\
\text { concrete sample at } 28 \text { days. }\end{array}$ \\
\hline
\end{tabular}

compressive strength relatively, but replacement quantity more than $50 \%$ will decrease the compressive strength and other properties in concrete mortar due to the level of pozzolanic reaction [34], therefore, percentage of cement replacement by waste material is limited [35]. Lim et al. [25] showed that ultrafine POFA (UPOFA) has a compressive strength value more than OPC and GPOFA at 28 days which was $105 \mathrm{MPa}$ for UPOFA and $84 \mathrm{MPa}$ for GPOFA. The high strength is due to the pozzolanic activity of the fine particle size of UPOFA and less carbon content. As shown in Figure 4, UPOFA has better compressive strength value than both OPC and GPOFA.

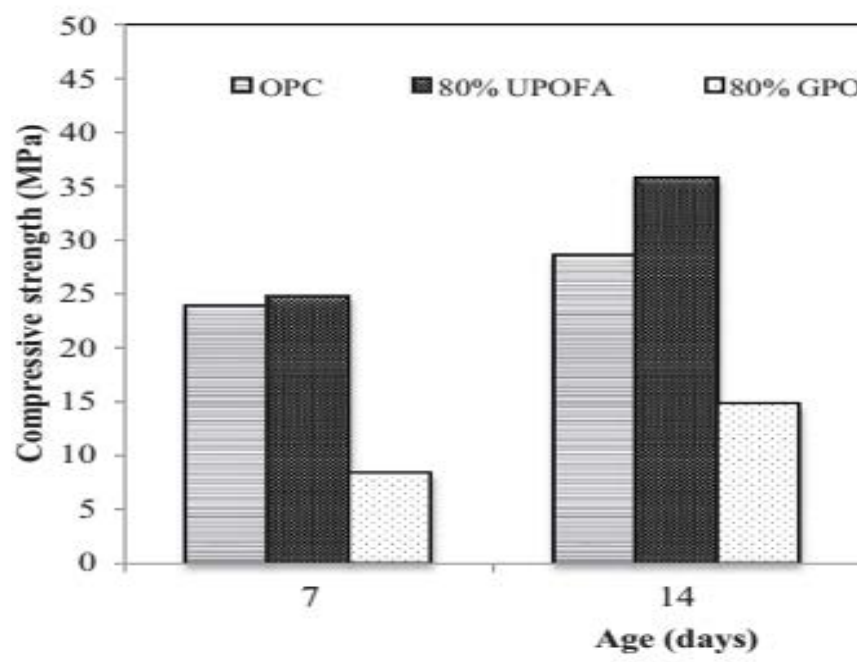

Figure 4: Compressive strength of concrete made of $O P C$, GPOFA, and UPOFA [25]

Although, adding more quantities of waste material to the concrete may lead to decrease in the compressive strength and decline in other characteristics but some researchers have noted that the $N$ anoparticles based waste materials give better performance if used as cement replacement [36, 37]. Farzadnia et al. [29] evaluated the influence of adding $\mathrm{N}$ ano silica on the concrete containing POFA as cement replacement on the shortterm drying shrinkage at 28 days and concluded that the compressive strength increases with adding Nano silica by $15 \%$ in the duration between 7 and 28 days of curing. A lso, Tangchirapat et al. [14] said that the compressive strength of concrete containing POFA as cement replacement by $0 \%, 10 \%, 20 \%$, and $30 \%$ with water/binder ratio 0.32 and binder content amount 550 $\mathrm{kg} / \mathrm{m} 3$, at 28 days was 58.5, 59.5, 60.9 and $58.8 \mathrm{MPa}$ respectively as shown in Table 1.

\subsection{Resistance to chloride and acid attacks}

Chloride penetration, sulfate attack, and carbonation are three factors that affect the durability directly due to exposure to the external aggressive environments [41, 42, 43]. The concrete components break down when exposed to acid attack; the dissolution of calcium hydroxide is the most pronounced [44]. The pozzolanic behavior and particles fineness of POFA ensures that it has a unique resistance for aggressive chemical materials such as chloride penetration, sulfate, acid and other materials, in addition to limiting the expansion resulting due to the alkali-silica reactivity [45]. POFA particles increase the resistance of concrete to the chloride ion penetration and acid environment $[30,46]$. The high strength concrete HSC including UPOFA in the composition has been used to protect the concrete from aggressive environment due to the delay in the migration time and chloride ion penetration needed to corrode the reinforced concrete [40], the results illustrated that the chlorine penetration rate values in concrete rises at the first three days of curing age, because of weak microstructural density, however for long time up to 90 days there is reduction in the value of penetration rate if compared with OPC.

\subsection{Resistance to sulfate attack}

POFA is one of the geopolymer binders and has been used as alternative to cement in concrete production because of its ability to resist sulfate attack, and enhance the compressive strength of the concrete [47]. M any researchers have shown that ground POFA can be obtained after grinding process with fine particles to ensure high surface area and good pozzolanic activity to replace cement and improve compressive strength and resistance to sulfate attack [47, 48]. Salami et al. [49] used POFA as a binder cementitious material with $100 \%$ engineered alkaline-activated cementitious composite (EACC) to produce concrete with resistance to sulfate attack. The concrete samples were immersed in three different solutions: $2.5 \%$ magnesium sulfate $+2.5 \%$ sodium sulfate solution, $5 \%$ magnesium sulfate solution, and $5 \%$ sodium sulfate solution. They used cubic samples with $50 \mathrm{~mm} \times 50 \mathrm{~mm} \times 50 \mathrm{~mm}$ of concrete mortar and then immersed in the same in three different solutions: mix of ( $\mathrm{MgSO} 4+\mathrm{Na2SO} 4$ ) or MgSO 4 or $\mathrm{Na2SO} 4$, for 28 days. The study concluded that there was a loss in the alkalinity 
of the POFA - mortar samples in the first few days of exposure of these samples to the sulfate solutions.

\section{Conclusion}

In this study, the advantages of POFA have been illustrated in the concrete mix especially regarding durability characteristics, hydration heat and drying shrinkage, compressive strength, resistance to chlorine and acid, and resistance to sulfate attack. POFA has good properties to enhance and improve the concrete durability especially with finer particles which is called ultrafine POFA, due to having high content of silica thus showing high pozzolanic behavior. In order to benefit from the POFA advantages in the concrete manufacturing, further experimental studies should be conducted to show the potential benefits of the incorporation of POFA in concrete mixtures

\section{References}

1. B. W icke, R. Sikkema, V. Dornburg and A. Faaij, "Exploring land use changes and the role of pal $\mathrm{m}$ oil production in Indonesia and M alaysia," Land Use Policy, 28, 193-206, (2011).

2. S. B. Hansen, R. Padfield, K. Syayuti, S. Evers, Z. Zakkariah and S. M astura, "Trends in global palm oil sustainability research," Journal of Cleaner Production, 100, 140-149,( 2015).

3. K. H. M O, U.J. A lengaram and M. Z. Jumaat, "A review on the use of agriculture waste material as lightweight aggregate for reinforced concrete structural members," Advances in Materials Science and Engineering, (2014).

4. Y . L. Chiew and S. Shimada, "Current state and environmental impact assessment for utilizing oil palm empty fruit bunches for fuel, fiber and fertilizer - A case study of M alaysia," Biomass and Bioenergy, 51, 109-124, (2013).

5. E. Olanipekun, K. Olusola and O. A ta, "A compartative study of concrete properties using coconut shell and palm kernel shell as coarse aggregates," Building and Environment, 41, 297301, 2006.

6. B. S. Thomas, S. K umar and H. S. A rel, "Sustainable concrete containing palm oil fuel ash as a supplementary cementitious material - A review," Renewable and Sustainable Energy Reviews, 80, 550-561, (2017).

7. M . F. A walludin, O. Sulaiman, R. Hashim and W. N. A. W. Nadhari, "A n overview of the oil palm industry in Malaysia and its waste utilization through thermochemical conversion, specifically vi liquefaction," Renewable and Sustainable Energy Reviews, 50, 1469-1484, ( 2015).
8. M. Gatto, M. Wollni and M . Q aim, "Oil palm boom and land-use dynamics in Indonesia: The role of policies and socioeconomic factors," Land Use Policy, 46, 292-303, (2015).

9. O. Sulaiman, N. Salim, N. A. Nordin, R. Hashim, M. Ibrahim and M. Sato, "The potential of oil palm trunk biomass as an al ternative source for compressed wood," BioResources, 7, 2688-2706, (2012).

10. H. M. Hamada, G. A. Jokhio, F. M. Y ahaya, A. M. H umada and $Y$. Gul, "The present state of the use of Palm Oil Fuel A sh (POFA) in concrete,"

Construction and Building Materials, 175, 26-40, (2018).

11. H. A bdel-Gawwad and S. A bo-El-Enien, "A novel method to produce dry geopolymer cement powder," HBRC Jouranal, 12, 13-24, (2016).

12. E. W orrell, L. Price, N. M artin, C. Hendriks and L. 0 . M eida, "Carbon dioxide emissions from the global cement industry," Annual Review of Energy and the Environment, 26, 303-329, (2001).

13. M. N . Fardis, "Innovative materials and techniques in concrete construction," in ACES Workshop, Springer Science \& Business Media, (2011).

14. W. Tangchirapat, C. J aturapitakkul and P. Chidaprasirt, "U se of palm oil fuel ash as a supplementary cementitious material for producing high-strength concrete," Construction and Building Materials, 23, 2641-2646, (2009).

15. V. Sata, C. J aturapitakkul and K. Kiattikomol, "U tilization of palm oil fuel ash in high-strength concrete," Journal of Materials in Civil Engineering, 16, 623-628, (2004).

16. H. M. Hamada, G. A. Jokhio, F. M. Y ahaya and A. M. Humada, "Properties of fresh and hardened sustainable concrete due to the use of palm oil fuel ash as cement replacement," in IOP Conference Series: Materials Science and Engineering,( 2018).

17. A . A . A wal and M . W . Hussin, "The effectiveness of palm oil fuel ash in preventing expansion due to alkali-silica reaction," Cement and Concrete Composites, 19, 367-372,( 1997).

18. H. M. Hamada, F. M. Y ahaya, K. M uthusamy, G. A. J okhio and A. M. Humada, "Fresh and hardened properties of palm oil clinker lightweight aggregate concrete incorporating Nano-palm oil fuel ash," Construction and Building Materials, 214, 344354, (2019).

19. M. A. A. Rajak, Z. A. M ajid and M. Ismail, "M orphological characteristics of hardened cement pastes incorporating nano-palm oil fuel ash," Procedia Manufacturing, 2, 512-518,( 2015). 
20. H. M. Hamada, G. A. Jokhio, F. M. Y ahaya and A. M. Humada, "A pplications of nano palm oil fuel ash and nano fly ash in concrete," IOP Conference series: Materials Science and Engineering, 342, no.1, p. 012068,( 2018).

21. M. Safiuddin, M. A bdus Salam and M. Z. Jumaat, "Utilization of palm oil fuel ash in concrete: a review," J ournal of Civil Engineering and Management, 17, 234-247, (2011).

22. A. A. A wal and M . W . Hussin, "Effect of palm oil fuel ash in controlling heat of hydration of concrete," Procedia Engineering, 14, 2650-2657, (2011).

23. S. B amaga, M. A . Ismail, Z. M ajid, M. Ismail and M. Hussin, "Evaluation of sulfate resistance of mortar containing palm oil fuel ash from different sources," Arabian Journal of Science and Engineering, 38, 2293-2301,( 2013).

24. X. Y. W ang and H. S. Lee, "M odeling the hydration of concrete incorporating fly ash or slag," Cement and Concret Research, 40, 984-996, (2010).

25. N. H. A. S. Lim, M. A. Ismail, H. S. Lee, M. W. H ussin, A. R. M. Sam and M. Samadi, "The effects of high volume nano palm oil fuel ash on microstructure properties and hydration temperature of mortar," Construction and Building Materials, 93, 29-34,( 2015).

26. J. H. Tay, "A sh from oil-palm waste as a concrete material," Journal of Materials in Civil Engineering, 2, 94-105,( 1990).

27. S. Tongaroonsri and S. T angtermsirikul, "Effect of mineral admixtures and curing periods on shrinkage and cracking age under restrained condition," Construction and Building Materials, 23, 10501056, (2009).

28. A . Itim, K. Ezziane and E. H. Kadri, "Compressive strength and shrinkage of mortar containing various amounts of mineral additions," Construction and Building Materials, 25, 3603-3609, (2011).

29. N. Farzadnia, H. Noorvand, A. M. Y asin and F. N. A. A ziz, "The effect of nano silica on short term drying shrinkage of POFA cement mortars," Construction and Building Materials, 95,636646,( 2015).

30. N. M. Altawir, M. M. Johari and S. S. Hashim, "Flexural performance of green engineered cementitious composites containing high volume of palm oil fuel ash," Construction and Building Materials, 37, 518-525, (2012).

31. N. Ranjbar, M. M ehrali, A. B ehnia, U. J. A lengaram and $M$. Z. J umaat, "Compressive strength and microstructural analysis of fly ash/palm oil fuel ash based geopolymer mortar," Materials \& Design, 59, no.2014, 532-539, (2014).

32. T. Deepak, A. Elsayed, N. H assan, N. Chakravarthy, S. Y. Tong and B. M ithun, "Investigation on properties of concrete with palm oil fuel ash as cement replacement," International Journal of Scientific \& Technology Research, 3, 138142,( 2014).

33. A. A. A wal and I. Shehu, "Evaluation of heat of hydration of concrete containing high volume palm oil fuel ash," Fuel, 105, 728-731, (2013).

34. D. Lin, K. Lin, W. Chang, H. Luo and M. Cai, "Improvements of nano-SiO2 on sludge/fly ash mortar," Waste Management, 28, 1081-1087, (2008).

35. K. Lin, W. Chang, D. Lin, H. Luo and M. Tsai, "E ffects of nano-SiO2 and different ash particle sizes on sludge ash-cement mortar," Journal of Environment Management, 88, 708-714, (2008).

36. M. M. K hotbehsara, E. M ohseni, M. A . Y azdi, P. Sarker and M. M. Ranjbar, "Effect of nano-CuO and fly ash on the properties of self-compacting mortar," Construction and Building Materials, 94, 758-766, (2015).

37. M. Sumesh, U. J. A lengaram, M. Z. J umaat, K. H. $\mathrm{M} \mathrm{O}$ and M. F. A Inahhal, "Incorporation of nanomaterials in cement composite and geopolymer based paste and mortar - A review," Construction and Building Materials, 148, 62-84,( 2017).

38. M. W. Hussin, N. H. A. S. Lim, A. R. M. Sam, M. A . Ismail, M. Samadi and N. F. A riffin, "Long term studies on compressive strength of high volume ultrafine palm oil fuel ash mortar mixes".

39. M. M. Johari, A. Zeyad, N. M. B unnori and K. A riffin, "Engineering and transport properties of high strength green concrete containing high volume of ultrafine palm oil fuel ash," Construction and Building Materials, 30, 281-288, (2012).

40. A. M. Zayed, M. A. M. Johari, B. A. Tayeh and M. $0 ., Y$ usuf, "Pozzolanic reactivity of ultrafine palm oil fuel ash waste on strength and durability performances of high strength concrete," Journal of Cleaner Production, 144, 511-522, (2017).

41. J. Zhang, C. Shi, Z. Zhang and Z. Ou, "Durability of alkali-activated materials in aggressive environments: A review on recent studies," Construction and Building Materials, 152, 598-613, (2017).

42. S. A. B ernal and J. L. Provis, "Durability of alkaliactivated materials: progress and prespectives," Journal of the American Ceramic Society, 97, 9971008, (2014).

43. M. Hossain, M. K arim, M. Hossain, M. Islam and M. F. M. Zain, "Durability of mortar and concrete 
containing alkali activated binder with pozzolans: A review," Construction and Building Materials, 93, 95-109, (2015).

44. F. Pacheco-Torgal, J. Castro-Gomes and S. Jalali, "Alkali-activated binders: A review: Part 1. Historic background, terminology, reaction mechanisms and hydration products," Construction and Building Materials, 22, 1305-1314, (2008).

45. M. W. Hussin and A. A. A wal, "Influence of palm oil fuel ash on sulfate resistance of mortar and concrete," Special Publication, 178, 417-430, (1998).

46. M. A ldahdooh, N. M . B unnori and M. M . Johari, "D evelopment of green ultra-high performance fiber reinforced concrete containing ultrafine pal $\mathrm{m}$ oil fuel ash," Construction and Building Materials, 48, 379-389, (2013).

47. W. Tangchirapat, T. Saeting, C. Jaturapitakkul, K. K iattikomol and A. Siripanichgorn, "U se of waste ash from palm oil industry in concrete,"
Waste Management, 27, 81-88, (2007).

48. C. Jaturapitakkul, K. Kiattikomol, W. Tangchirapat and $T$. Saeting, "Evaluation of the sulfate resistance of concrete containing palm oil fuel ash," Construction and Building Materials, 21, 13991405, (2007).

49. B. A. Salami, M . A. M . Johari, Z. A . A hmad and M. $M$ aslehuddin, "Durability performance of palm oil fuel ash based engineered alkaline-activated cementitious composite (POFA-EACC) mortar in sulfate environment," Construction and Building Materials, 131, 229-244, (2017). 